Int. J. Dev. Biol. 52: 121-134 (2008)

doi: $10.1387 /$ ijdb.072376at

\title{
Mammalian and avian embryology at the University of Warsaw (Poland) from XIX century to the present ${ }^{\#}$
}

\author{
ANDRZEJ K. TARKOWSKI*, MAREK MALESZEWSKI, TERESA ROGULSKA, MARIA A. CIEMERYCH \\ and EWA BORSUK \\ Department of Embryology, Institute of Zoology, Faculty of Biology, University of Warsaw, Poland
}

\begin{abstract}
In this article, we describe the history (between the XIX century and World War II) of embryological research conducted at Warsaw University, together with current research activities being carried out at the Department of Embryology. During the partition of Poland, the Imperial (Russian) Warsaw University conducted research on avian embryology (and to a smaller extent, on reptilian embryology). When Poland regained independence in 1918, these studies were continued under the Chair of Comparative Anatomy headed by Professor Jan Tur. A new Department of Embryology created in 1954 was first headed by Professor Stanislaw Bilewicz and since 1964 by Professor Andrzej Tarkowski, who in 2003 was succeeded by Dr. Marek Maleszewski D.Sc. During the last 45 years, embryological research at Warsaw University has concentrated mainly on mammalian development with special emphasis on the regulative capabilities of early embryos and also on experimental chimaeras, nucleo-cytoplasmic interactions in oogenesis and early embryogenesis (including regulation of DNA replication and transcription), experimental parthenogenesis and fertilization.
\end{abstract}

KEY WORDS: mouse, regulative development, chimaerism, cell lineage, fertilization

\section{The beginnings: XIX century - 1939}

Poland lost independence in the XVIII century after she was partitioned between Russia, Prussia and Austria from 1772 to 1795. In the times that followed, many Polish scientists studied and often lived abroad, and many foreigners came to work in Polish academic institutions. In 1816 Alexander I, the Emperor of Russia and the usurper King of Poland, granted permission for the establishment of Warsaw University. The University followed the tradition of three earlier institutions of higher education: Collegium Nobilium, opened in 1766, the School of Law (founded in 1808 ) and the School of Medicine (founded in 1809). The University still bears the emblem described as "an ancient Polish eagle with a crown, with spread wings, a palm frond in its left claws and laurel branch in its right, the symbols of patient diligence and honour, surrounded by five stars representing its five academic faculties". These faculties were theology, law, medicine, philosophy, and the liberal arts. After the fall of the November 1830 uprising, in which a majority of students had participated, the University was closed in 1831. In 1857 there was a brief period of liberalization that resulted in the opening of the Main School (Szkola Glowna) with the departments of medical-surgical, law and administration, philological-historical, and mathematics-physics. The Main School was closed in 1869, on the wave of increasing oppression and russification after the fall of the second, the January 1863 uprising. However, in the short period of the existence of the Main School as many as three thousand students graduated and the School had great impact on the development of Polish science and culture. In 1870, the Russian Imperial University was opened in Warsaw. The majority of faculty teachers were Russians and the official (teaching) language was Russian. Steadily the University expanded: new buildings were constructed; academic potential increased and precious zoological and botanical collections were created.

The Department of Comparative Anatomy was founded in 1870. It was headed by Russian scientists: Mitrofan Ganin (187084), Mitrofan Uljanin (1884-1888) and Pawel Mitrofanow (Mitrophanow) (1888-1914). Mitrofanow (Fig. 1) was an outstanding avian embryologist working mainly on early embryos; in papers published in 1895 and 1899, he presented evidence that

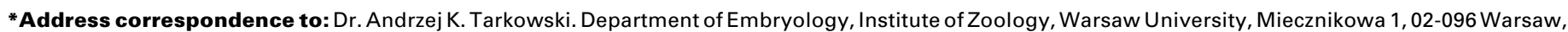
Poland. Fax: +48-22-55-41-210. e-mail: akt@biol.uw.edu.pl

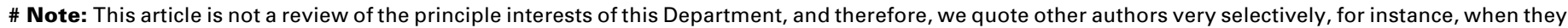

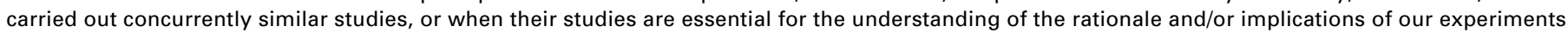

Published online: 14 February 2008

0214-6282/2008/\$35.00

(C) UBC Press

Printed in Spain 


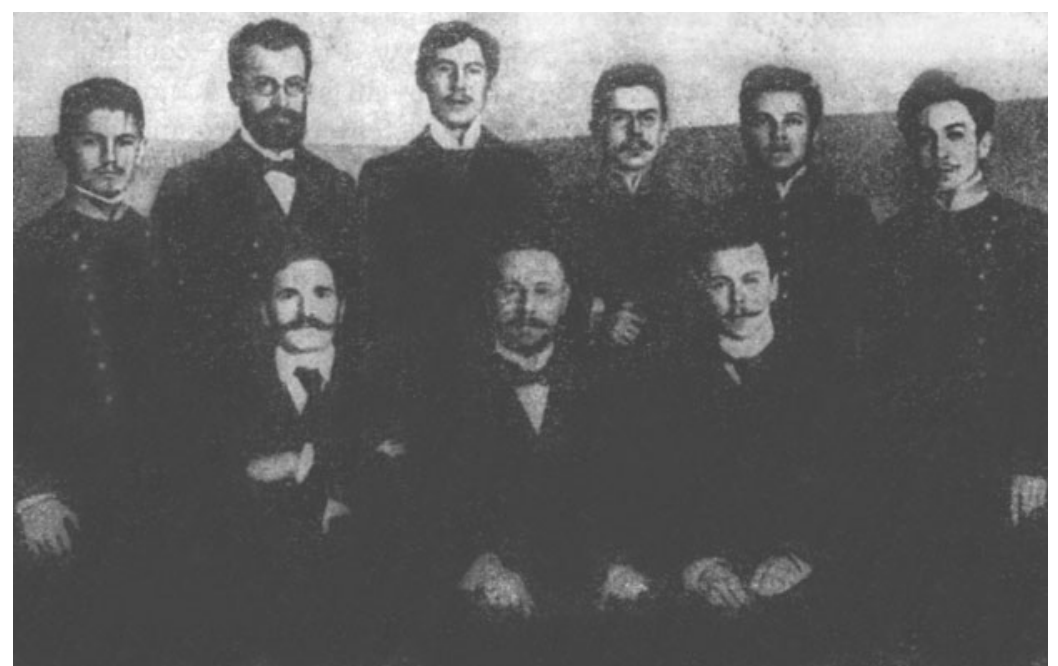

Fig. 1. Pawel Mitrofanow and his students and collaborators, Warsaw (1904). Standing, from the left: A. Chainski and Justow (Russians), Kazimierz Stolyhwo, Mieczyslaw Konopacki, Stanislaw Minkiewicz and Kazimierz Bialaszewicz; sitting, from the left: Jozef Eismond, Pawel Mitrofanow and Jan Tur.

the endoderm in birds derives from the epiblast. His studies were often quoted in the 'opus magnum'of avian embryology, 'The Avian Embryo', by A.L. Romanoff (1960). He was also an excellent teacher who had educated many Polish students, including some who later became well known professors - Jan Tur, Jozef Eismond, Mieczyslaw Konopacki.

Another prominent scientist that held the title of professor of histology, embryology and comparative anatomy was Henryk Fryderyk Hoyer (1834-1907), known mostly for histological studies on arterio-venular anastomoses (which were often named after him) and as an author of the first textbook of histology in Polish, published in 1862. After receiving Ph.D. degree at the University of Berlin he came to Warsaw and worked at School of Medicine (1860-61), Main School (1862-68) and the Imperial Warsaw University (1870-94). Among his most eminent students was Waclaw Mayzel (1847-1916)) who in 1875, concurrently with other scientists (but independently of them) described mitosis in animal cells. He studied also fertilization and cleavage in nematodes and molluscs and early stages of embryonic development in plants. One of the most outstanding students of the University was Jozef Nusbaum-Hilarowicz (1859-1917) who studied at the Chair of Comparative Anatomy between 1878-81, but received his first degree in zoology and comparative anatomy from the University of Odessa in 1886, where his advisors were two famous Russian biologists, A.O. Kowalewskij and I.J. Miecznikow. Jozef NusbaumHilarowicz returned to Warsaw University to receive his Ph.D. degree, but because of the anti-Jewish law imposed by Russians, the University was not permitted to employ him. Nusbaum-Hilarowicz moved to Lwow in Austrian partition, where he became professor and head of the Chair of Zoology and Comparative Anatomy at Lwow University. In 1887 he published the first Polish textbook of embryology entitled 'General principles of animal development', and was an enthusiast and promoter of the ideas of Darwin.

The Imperial Warsaw University ceased to exist with the outburst of the First World War (1914) and retreat of Russians from Warsaw. In 1915 the German authorities reopened the University which in 1918 - when Poland regained independence became one of the first legally functioning Polish national institutions. Soon, many distinguished specialists and professors of Polish nationality had moved from Russia, the former Austrian Empire, Germany, and from other parts of the world to join Warsaw University.

Jan Tur (1875-1942) (Fig. 2) became the head of the Department of Comparative Anatomy in 1916 and remained at this post until 1939, when the World War II began and the University was closed. He published about 120 original papers on teratology, descriptive embryology and comparative anatomy. Tur and his collaborators analysed in detail the development of spontaneous twin and multiple avian embryos (Fig. 3). At that time there were many speculations concerning the origin of identical twins and 'double monsters'. For example, Gustaw Dehnel (later he used the first name August), a student and collaborator of Tur, studied early development of the freshwater turtle. His observation of the presence in the individual female of binucleate and multinucleate ovarian oocytes and blastoderms with two embryos was the basis for his, as we now know incorrect hypothesis, that at least in reptiles and birds, twin embryos develop from binucleate oocytes (Dehnel, 1929a). At that time Dehnel also started to experiment on chick embryos. However, Tur was not an enthusiast of experimental approach (such as - for example - splitting of the blastoderm) to the problem of the origin of twins and his preferable approach was to study naturally occurring abnormalities. Consequently, he did not appreciate Dehnel's experiments of bisecting, previously incubated for a short time, chick blastoderm with a weak direct electric current what resulted in duplication of some embryonic structures (as we know now only the non-incubated avian blastoderm has full regulative potential). This 'methodological' disagreement between Tur and Dehnel had negative impact on Dehnel's publication record: he published only a preliminary report of his experiments in French and a full text in Polish (Dehnel, 1929b, 1933) and eventually left the Department.

Tur was also interested in the teratogenic effects of radium radiation on embryos, and between 1904 and 1916 he published several papers on the development of irradiated embryos of the chick, duck, shark (Scyllium canicula) and two species of clams (his 1904 paper was one of the first two on this subject; Tur, 1904).

Tur had educated many students, and some of them became later, after World War II, professors or lecturers at Warsaw University (Stanislaw Bilewicz, Zygmunt Kraczkiewicz, Wladyslaw Szaniawski), at University of Maria Curie-Sklodowska in Lublin and in Polish Academy of Sciences (August Dehnel), and at University of Geneva (Jerzy Gallera). Department of Comparative Anatomy with its quarters, equipment and scientific materials and documentation was devastated during the Second World War, and when the Warsaw University began functioning again in 1945, the Department did not recover and in 1948/1949 it was officially closed. However, the tradition of embryological research survived.

\section{From 1954 to the present times}

In 1954 a new Department of Embryology was created with Stanislaw Bilewicz (1903-1962) as an associate professor and 
head. Initially only two young assistants were employed (Danuta Wozniak and Waclaw Ozdzenski). In the first years of the existence of the laboratory the main task of the staff was to acquire the equipment necessary for research (microscopes, incubators etc) and teaching - a certain number of histological samples and embryological wax models 'survived' the war in the university buildings appropriated by the German police, but the majority of teaching aids had to be prepared from scratch. The number of students doing M.Sc. degree in embryology started to grow and by 1960 eight students had graduated with M.Sc. thesis on the reproduction of mouse, bream, fruit fly and frog.

In 1962 professor Bilewicz died, and the department was supervised by professor Kraczkiewicz (see Kloc, 2008 in this issue, pp. 115-119) as a curator until 1964, when Dr. Andrzej K. Tarkowski (employed at that time as an adjunct in the neighbouring Department of Zoology) received his D.Sc. degree and was appointed head of the laboratory as an associate professor (docent) (Fig. 4). Tarkowski re-oriented the programme of the laboratory along his research interest, which was the experimental embryology of the mouse, and particularly the regulative capabilities of preimplantation mouse embryos and experimentally produced chimaeric mice. His first students received their M.Sc. degrees in 1964; among them was Joanna Wroblewska whose thesis contributed substantially to further experimental

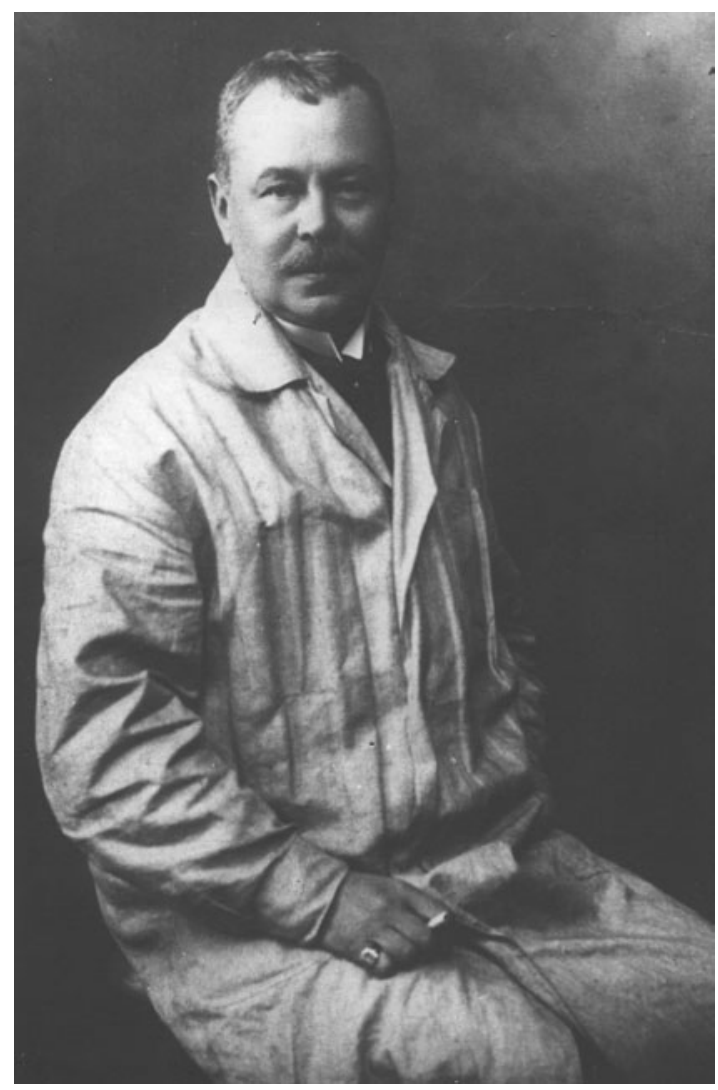

Fig. 2. Prof. Jan Tur in Warsaw (1926). Professor Tur headed the Chair of Comparative Anatomy at Warsaw University since 1916 until World War II, when the University was closed by Germans. He was interested mostly in descriptive avian embryology and teratology, and has educated many scientists who became professors after WW II.

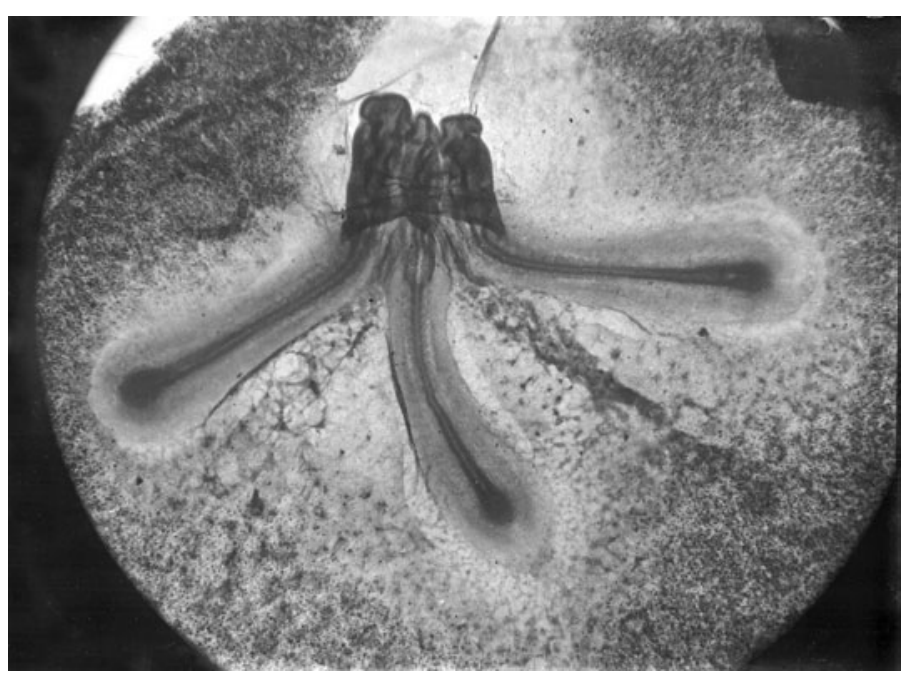

Fig. 3. An example of a rare case of a spontaneous triple chick embryo. Figure printed from an original glass photographic plate; photograph taken by Wladyslaw Szaniawski, sometime between 1922 and 1939. Szaniawski received his PhD in 1922 las one of the first - if not the first - in the re-opened Warsaw University), and Jan Tur was his PhD advisor.

studies on early mouse development.

With the retirement of Professor Tarkowski in 2003 (Fig. 6), Dr. Marek Maleszewski, D.Sc., became the Head of the Department.

\section{Regulative capacities of early mammalian embryos: devel- opmental potential and fate of single embryonic cells}

The question of the developmental potential of single mouse blastomeres was first approached by Tarkowski in 1959 (Tarkowski, 1959a,b) when he showed that one of the first two blastomeres is totipotent, i.e. is able to develop into an animal. Although this study did not establish whether both first blastomeres have the same developmental potential, other laboratories showed later that occasionally both blastomeres could develop into twins. Similar attempts to produce mice from single blastomeres of a 4-cell embryo failed (Rossant, 1976) and it was concluded that this developmental failure was due to inadequate number of cells in the inner cell mass (ICM) (or even lack of this structure) in experimental blastocysts (ICM provides cells for the embryo proper whereas the outside layer of cells, the trophectoderm, forms extra-embryonic structures). There have been various attempts to overcome this problem by supporting the development of single blastomeres with other cells, diploid or polyploid, in hope that this would help the progeny of the tested blastomere to become preferentially allocated into the embryo proper. We have used tetraploid rather than diploid blastomeres as the supporting cells. The advantage of using $4 \mathrm{n}$ blastomers consisted in that they were progressively eliminated from the embryonic derivatives of ICM, and only occasionally traces of $4 \mathrm{n}$ cells persisted until an adulthood (Tarkowski et al., 2001a). Using this experimental system we showed that at least two out of four sister blastomeres and three out of eight sister blastomeres can develop into adult fertile animals (Tarkowski, et al., 2001a, 2005a). These experiments leave open the question whether all blastomeres of the 4- and 8-cell embryo have similar developmental potential, i.e. are capable to develop into an animal. In fact two pieces of 


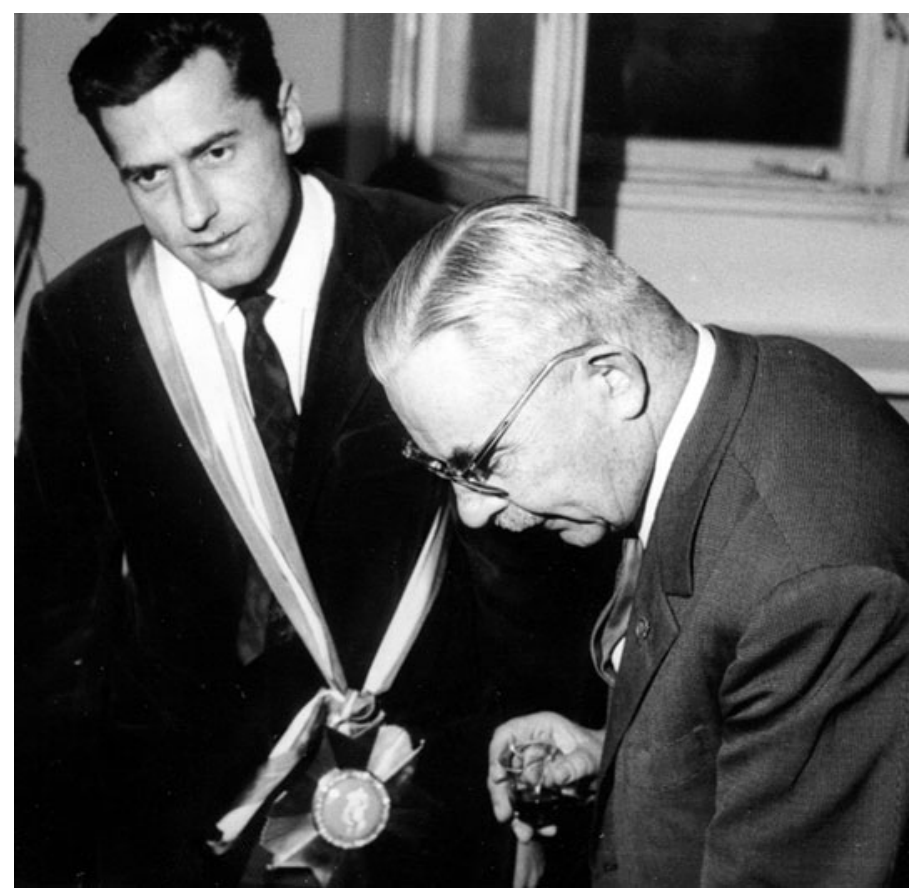

Fig. 4. Professor Zygmunt Kraczkiewicz (right) and associate professor Andrzej K. Tarkowski at Tarkowski's name day party in 1970 at Warsaw University. In Poland, name day is celebrated more often than birthday. Tarkowski wears an 'Order of the Mouse Garter' offered to him by his collaborators (see Fig. 5).

evidence appear to contradict such a possibility. First - when individual mouse blastomeres obtained from 4-cell embryos differing in pigmentation are aggregated in 1:3 and 2:2 ratio, the observed ratio of chimaeric to non-chimaeric animals supports the hypothesis that three blastomeres contribute to the animal's body (Tarkowski et al., 2001b). Second - in the case of a certain specific pattern of cleavage, which occurs in some embryos, one blastomer differs from the remaining three in its developmental potential: chimaeric embryos made by aggregation of such blastomeres do not develop normally (Piotrowska-Nitsche et al., 2005).

Interesting as they are, the attempts to produce animals from single blastomeres originating from the consecutive cleavage stages have not answered the question when and why the blastomeres become different from each other, i.e. some generate ICM cells and other form the trophectoderm cells. One of the possible approaches to address this question is to compare the development of all isolated sister blastomeres in vitro. This type of experiment was first carried out in our laboratory over 40 years ago. The study of Tarkowski and Wroblewska (1967) was a basis for the 'inside-outside' hypothesis according to which the decision of whether a blastomere will contribute to ICM or trophectoderm is epigenetic and depends on its position (outside versus inside) within the multicellular morula. It is still unknown what is the molecular nature of this vague "positional" signal causing the cleaving cells to diverge in their fate.

In the recent decade the interest in an early mouse embryo increased again mainly due to the studies carried out in Cambridge by our colleague and former member of the staff of our Department, Magdalena Zernicka-Goetz. She has postulated the existence in the mouse egg of a certain pre-pattern that normally (i.e. when the embryo is not disturbed by experimentation) is followed by the developing embryo and may predispose early blastomeres to different fates (reviewed by Zernicka-Goetz, 2002, 2005, 2006). In contrast, experimental data from our laboratory indicate that at least the first two blastomeres are not prepatterned in their fate, and neither of them is predisposed to form ICM or trophectoderm (Chroscicka et al., 2004; Waksmundzka et al., 2006).

\section{Experimental chimaerism}

Studies on experimental mouse chimaeras started by Tarkowski in the Department of Zoology at the University of North Wales in Bangor (Tarkowski, 1961), were continued in Warsaw with crucial contribution of Dr Ewa Mystkowska. Dr Mystkowska graduated in Zoology at Warsaw University and obtained Ph.D. in comparative anatomy. In 1965 she started to work in the Institute of Mother and Child Health, and later in the Hospital of Obstetrics and Gynaecology headed by Professor Ireneusz Roszkowski, who assigned her with a task of organizing the Laboratory of Experimental Embryology and sent her for training in our department. During this training she did an excellent job by making bi-coloured chimaeras and by providing karyological evidence of the sex chromosome chimaerism of true hermaphrodites and of those fertile males that sired progeny of one genetic type only (these males produce spermatozoa only from germ cells derived from the male component of a chimaera) (Mystkowska and Tarkowski, $1968,1970)$. These studies also showed that in contrast to lower vertebrates the genetically female germ cells were unable to complete spermatogenesis and to form spermatozoa. Although this conclusion could have been probably deduced on the basis of the knowledge of mammalian genetics already available at that time, it was still an open question, and its experimental confirmation was needed and valuable. During 1970ties Dr Mystkowska continued to collaborate with our laboratory, mainly with $\mathrm{Dr}$ Waclaw Ozdzenski. They studied preimplantation development of the bank vole (Mystkowska, 1975a; Ozdzenski and Mystkowska, 1976a,b), mouse chimaeras (Mystkowska et al., 1979) and interspecific mouse<->bank vole chimaeras (Mystkowska, 1975b). Two of our former Ph.D. students, Dr. Aldona Komar and Dr. Anna Niemierko, joined Mystkowska's laboratory, which was closed in 1979, and all three of them had transferred to the Department of Histology and Embryology in the Medical School in Warsaw.

Our interest in the phenomenon of chimaerism has continued. Recently, Suwinska etal. (2005) described a successful attempt to generate diploid<->triploid chimaeras in the mouse. Using traditional technique of embryo aggregation we have produced several foetuses and adult animals, whose chimaerism has been confirmed by pigmentation and GPI isozymes markers. In contrast to diploid/tetraploid chimaeras, in which $4 \mathrm{n}$ cells are totally eliminated during embryogenesis, or remain in adult animals only in vestigial numbers, in $2 n<->3 n$ chimaeras the triploid cells survive in many tissues, sometimes in substantial numbers, and without visible adverse effect on the viability of animals.

We have also shown that mouse chimaeras can be produced from such an advanced embryos as blastocysts. However, to achieve this effect it is first necessary to induce local fusion of the trophectoderm of the two blastocysts by Sendai virus or electric impulses. Depending on the mutual position of the ICMs of the 
aggregated embryos, the resulting single chimaeric blastocyst can have two separate ICMs or single ICM (Tarkowski and Wojewodzka, 1982; Tarkowski et al., 2005b). After implantation, the blastocysts with two separate ICMs form two separate eggcylinders, but only some of them develop into dizygotic twin foetuses (Ozdzenski etal., 1997). The blastocysts with single ICM develop into single chimaeric foetuses and animals. These experiments indicate that by the stage of medium sized/early expanded blastocyst, the spatial organisation (including the axis of bilateral symmetry) of ICM still remains labile (Tarkowski et al., 2005b).

\section{Primordial germ cells in the mouse}

Observations of the fate of germ cells in chimaeras stimulated our interest in the origin and migration of primordial germ cells (PGCs) in the mouse embryo. In 1967 Ozdzenski showed that PGCs are present in the rudiment of allantois and in the posterior region of the primitive streak as early as at the presomite stage. Although the presence of PGCs in the hind region of the embryo was already known at that time, it was not clear what is their primary location in the embryo.

Later, Ozdzenski studied the fate of PGCs trapped in the excised hindgut and transplanted to an ectopic site, the anterior chamber of the eye (Ozdzenski, 1969). The final fate of these PGC's remains unknown because the positive reaction for the PGGs marker, the alkaline phosphatase, lasted only for a couple of days. The parallel studies on bird PGCs carried out in this laboratory resulted in an interesting combinatorial experiment in which the excised hind gut of a mouse embryo containing migrating PGCs was transplanted into the coelomic cavity of the young chick embryo (Rogulska et al., 1971). These experiments showed that mouse PGCs in the graft tended to accumulate in the close vicinity of the chick gonadal rudiment. These observations were among the first suggesting that the factor attracting migrating germ cells in vertebrates is not species (or even class) specific.

We also focused our attention on the initiation of meiosis by PGC's. Mystkowska and Tarkowski $(1968,1970)$ observed that in gonads of some chimaeric newborns there were regions in which early oocytes co-existed with pre-spermatogonia typical for testes of late foetuses and early neonatal young. This observation led to the question whether the route of gametogenesis in the gonads of sex-chimaeras depends on their genetic sex or on the external stimuli exerted locally by the surrounding somatic cells? This question led inevitably to the next, more fundamental question: is the initiation and course of gametogenesis programmed by intrinsic factors or is it under external control of the somatic tissue of the gonad. All earlier studies on lower vertebrates pointed to the second alternative. Unfortunately, we could not answer this question because we were unable to determine the genetic sex of the cells in question. We looked, therefore, for a simpler model. Ozdzenski (1972) transplanted the genital ridges to an ectopic site, the surface of the kidney of adult hosts. Although the histological differentiation of the genetically male genital ridges was rather poor, some of the germ cells - and in this case all of them were certainly genetically male - entered into meiosis. The same situation was observed when early testes were transplanted (Ozdzenski and Presz, 1984). Moreover, the initiation of meiosis in the transplanted male gonads coincided with the reinitiation of meiosis in control embryonic ovaries. This observation together with observations from other laboratories (for example on the development of early oocytes from ectopic PGCs in the adrenals of male foetuses (Upadhyay and Zamboni, 1982), suggested that initiation of meiosis, in the ovary and ectopically, occurs by default, i.e. does not require any definite, inducing stimulus. In contrast, the inhibition of mitotic divisions and impediment of meiosis observed normally in foetal testes requires specific signal from the surrounding somatic tissue. This interpretation does not explain, however, why in tissues other than the testicular tissue meiosis is initiated at a definite stage of embryonic development. This question still remains unanswered.

\section{Avian embryology}

In the middle sixties, Teresa Rogulska initiated embryological studies in birds in our Department. First she studied the regulative capacities of early duck blastoderm. Studying the effect of transection of the non-incubated blastoderm on the orientation of embryos (either twins or single embryo developed despite the cutting) she confirmed earlier studies pointing to the regulative capacities of duck blastoderm and found that the embryonic axis of the non-incubated blastoderm is not irrevocably fixed (Rogulska, 1968a). Using the same experimental approach Rogulska found also that each half of the blastoderm is able to form both the embryo and the PGCs (Rogulska, 1968b). Later she continued to work on chick and Japanese quail embryos studying the natural, spontaneous and transient feminization of the left embryonic quail testis with the emphasis on the timing of meiotic prophase in the cortical region (Rogulska and Zajac, 1986-87). Rogulska also studied the determination of testicular asymmetry using interspecific transplantation of embryonic testes (Rogulska et al., 1992). Later, using chick and quail embryos she studied intravascular migration of PGCs and colonization of gonadal rudiments (Kuwana and Rogulska, 1999).

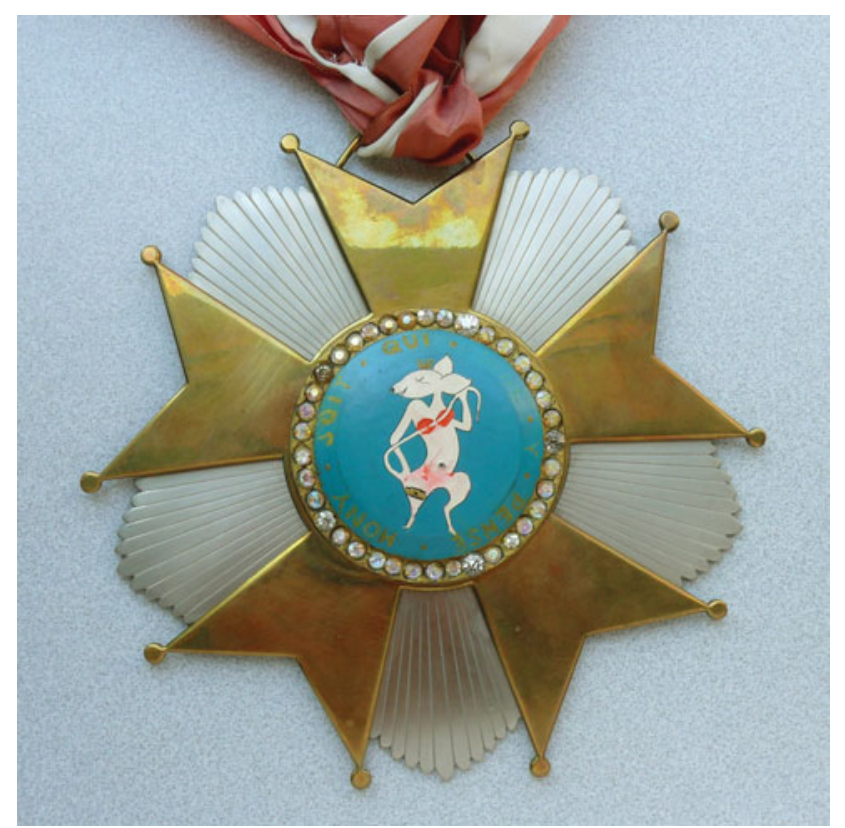

Fig. 5. An 'Order of the Mouse Garter' under magnification (the mouse's panties have faded over 37 years!). See also Fig. 4. 


\section{Developmental effects of polyploidy and haploidy on mouse embryogenesis}

Incidental observation of abnormal triploid postimplantation mouse embryo stimulated us to undertake systematic search for triploid embryos in pregnant CBA females crossed with CBAT6T6 males carrying marker chromosomes. Wroblewska (1971) found that: (1) in this genetic background triploidy inhibited mostly the development of the embryonic part of the egg-cylinder, and temporarily did not affect the foetal membranes, and (2) all observed cases of spontaneous triploidy were due to digyny, i.e. retention of two maternal sets of chromosomes (as shown by the presence of only one T6 marker chromosome). This study stimulated us later to induce triploidy experimentally: in 1975 Niemierko described a simple and reliable method of cytochalasin B suppression (soon after sperm penetration) of the second polar body extrusion. Among other anomalies, the triploid embryos were also produced by subjecting zygotes to short hypotonic (distilled water) treatment (Opas, 1977).

Cytochalasin B proved also very useful in producing tetraploid embryos and diploid<->tetraploid mosaic embryos by suppression of the second cleavage division in both or in one blastomere respectively (Tarkowski et al., 1977). Independently, similar experiments were carried out in Great Britain by Snow (1973). While our tetraploid embryos consistently displayed severe abnormalities in the embryonic part of the egg-cylinder (more severe than those observed in triploid embryos) and invariably died at the beginning of the second half of pregnancy, Snow produced several foetuses that survived until birth but died soon afterwards. As this observation has never been repeated, the reasons of success of Snow's experiment remain unexplained. Our studies on $4 \mathrm{n}$ and $2 \mathrm{n}<->4 \mathrm{n}$ embryos also showed that in postimplantation development of diploid<->tetraploid mosaics the tetraploid cells are eliminated from the embryo proper but survive and function in the extra-embryonic membranes. This observation stimulated us (and probably others) to use tetraploid embryos or blastomeres as carrier cells in producing mice from ES cells (first application: Nagy et al., 1990) or from single blastomeres of 4- and 8-cell embryos (Tarkowski, et al., 2001a, 2005a).

Attempts to produce haploid embryos were undertaken in a hope that such embryos might become a source of haploid cell lines that, in turn, could be used in studies on the expression of recessive alleles. This aim has not been achieved so far, but haploid embryos produced by sophisticated microsurgery (Modlinski, 1975), bisection of zygotes (Tarkowski and Rossant, 1976; Tarkowski, 1977), or simply by artificial activation (see below: parthenogenesis) have proved very useful in a variety of embryological experiments.

\section{Experimental parthenogenesis and gynogenesis}

For one of us (AKT), and perhaps for other scientists as well, the motivation to produce mammalian parthenogenetic embryos and adults was not only a scientific curiosity but also a general human curiosity about the possibility of parthenogenesis in our own species (if it is possible in the mouse, the rabbit...then????). After the initial promising reports by Pincus in the thirties/forties and less encouraging findings by Chang and Thibault in the forties/fifties (for references see Tarkowski et al., 1970), in the late sixties - when we started the experiments - this subject was not in vogue any more. Shortly, however, it became very trendy. The article by Tarkowski et al. (1970) was published in Nature concurrently with the article describing the results of similar studies conducted by Christopher F. Graham in Oxford (Graham, 1970), and it was followed by two detailed studies by Witkowska (1973a,b). Further studies concentrated on testing new activation stimuli, such as heat shock (Komar, 1973) and on the attempt to routinely produce diploid parthenogenetic embryos (for example: combination of heat shock technique with cytochalasin, Balakier and Tarkowski, 1976). The most important finding of our studies was that parthenogenetic embryos could develop as far as to the stage of early organogenesis (our most advanced embryo was at the 8somite stage). The intriguing issue was also what are the causes of the very high postimplntation mortality of embryos, which could not have been explained simply by haploidy, because many of our embryos were diploid. Later, many different laboratories confirmed the existence of such developmental barrier for diploid parthenogenotes and Kaufman et al. (1977) was able to increase the survival of diploid parthenogenote to the 35-somite stage. One of the possible explanations was that parthenogenotes die because of the lack of a hypothetical extra-nuclear factor introduced normally by sperm. Although this hypothesis did not seem very probable, we decided to test it, and Borsuk (1982) produced gynogenetic blastocysts from fertilized eggs in which the second polar body was first suppressed and then the male pronucleus was microsurgically removed. Unfortunately we did not follow up on these interesting findings. The decisive step was made soon by Surani etal. (1984) and Mc Grath and Solter (1984) who proved beyond any doubt that gynogenetic embryos, which like parthenogenetic embryos contain two maternal haploid genomes, were unable to survive beyond the stage of early organogenesis. In addition, McGrath and Solter (1984) showed that the same is true for embryos with two paternally derived genomes. These were very important contributions to the discovery of the phenomenon of gametic imprinting.

\section{Nucleo-cytoplasmic interactions in oocyte maturation and early development}

The application of the techniques of cell fusion (Sendai virus, polytethelene glycol and electric impulses) and microsurgery to mammalian oocytes and early embryos allowed us to study the nucleo-cytoplasmic interactions in oocyte maturation and early development. Cell fusion techniques permitted us to repeat experiments performed by Masui and Markert (1971) on frog oocytes, without microsurgical injection of cytoplasm, which is difficult to perform in small mammalian eggs and early embryonic cells. Masui and Markert (1971) proposed that during oocyte maturation the condensation of chromosomes is induced by 'maturation promoting factor' (MPF), a hypothetical cytoplasmic factor (currently it is known that MPF is a protein kinase composed of two subunits - catalytic-CDK1 and regulatory cyclin B). Soon it was proposed that similar factor operates during mitosis in somatic cells, and a term M-phase promoting factor was introduced. We proved that similar system functions during maturation of mouse oocytes and in cleavage divisions. Using the method of cell fusion, Balakier and Czolowska (1977) and Balakier (1978) showed that the premature condensation of chromosomes in GV mouse oocytes can be induced by a cytoplasmic factor present in mitotic blastomeres, and vice versa, the premature chromosome condensation in interphase blastomeres can be induced by the 
cytoplasm of maturing oocytes. Moreover, using the combination of two species - mouse and bank vole - Balakier found that this factor is not species specific (Balakier, 1979). Today, when the molecular basis of both meiotic and mitotic cell cycle is precisely known, it sounds unbelievable that thirty years ago these basic cellular events were explained only in terms of a hypothetical and enigmatic cytoplasmic factor.

Combination of techniques of cell fusion and microsurgery permitted us to show that the activity of MPF in ovulated oocytes decreases with their postovulatory age, and that it is localized mainly in the spindle of metaphase II and/or in the surrounding cytoplasm. These conclusions were based on the results of experiments in which nucleate and anucleate oocyte fragments of various size were fused with interphase blastomeres from 2- and 8-cell embryos (Czolowska et al., 1986). We also demonstrated that the exposure of zygote's pronuclei to MPF of metaphase II oocyte leads to differential condensation of the male and female pronuclei (Ciemerych and Czolowska, 1993), the phenomenon that, as we presently know, can be explained by asymmetric organisation of the two genomes in the mouse zygote (reviewed by Reik et al., 2003).

Studies by Masui and Markert (1971) postulated the presence in the mature frog oocyte of another cytoplasmic factor, the cytostatic factor (CSF), i.e. the activity responsible for arresting the ovulated oocyte in the metaphase of second meiotic division (metaphase II). In 1993 Kubiak and his colleagues confirmed the existence of a similar cytoplasmic activity in metaphase II mouse oocytes. Later, the mechanism of chromosome condensation during oocyte maturation, and the molecular background of the meiotic and early embryonic mitotic cell cycles have been extensively studied by Ciemerych and Kubiak (Ciemerych and Czolowska, 1993; Ciemerych, 1995; Ciemerych, 1998; Ciemerych etal., 1998; Ciemerych and Kubiak, 1998, 1999; Ciemerych et al., 1999; Kubiak and Ciemerych, 2001). Searching for mouse CSF Kubiak (working at that time in Bernard Maro's laboratory in Paris) fused metaphase II arrested oocytes with one-cell haploid parthenogenetic embryos at the G2 stage of the cell cycle. MPF present in the cytoplasm of metaphase II oocyte induced premature chromosome condensation (PCC) of the chromatin of G2 nucleus. Importantly, the resulting hybrids remained permanently arrested in M-phase proving that CSF is active also in mouse oocytes (Kubiak et al., 1993). The choice between parthenogenetic embryos and zygotes obtained after fertilization was - quite unwittingly - crucial for the result of this experiment. Kubiak and his colleagues did not foretell the differences existing between both types of one-cell embryos. In 1995, Zernicka-Goetz and colleagues showed that in contrast to hybrids studied by Kubiak, those produced from metaphase II oocytes and zygotes never arrested in M-phase but underwent activation and progressed into interphase. The reason of such differences was attributed to the calcium oscillations that persist in the cytoplasm of fertilized but not parthenogenetically activated oocytes and trigger the signaling pathway leading to the inactivation of both MPF and CSF (Kono et al., 1995; Zernicka-Goetz et al., 1995). The dynamics of CSF activation and inactivation was further studied by Ciemerych and Kubiak. First, using oocytes of the LT/Sv strain of mice, that are characterized by the prolonged metaphase I, they discovered that under the conditions preventing the onset of anaphase, the cytostatic activity develops earlier then in metaphase
II (Ciemerych and Kubiak, 1998). Second, they described the dynamics of CSF disappearance after oocyte activation and showed for the first time that CSF is inactivated in the biphasic manner (Ciemerych and Kubiak, 1999). Concurrently, Ciemerych has been studying the peculiarities of the first mitotic cycles in the mouse embryo (Ciemerych, 1995; Ciemerych et al., 1998, 1999; Sikora-Polaczek et al., 2006). The first of these experiments was based on the observation of Waksmundzka and collaborators who studied cortical activity in one-cell mouse embryos (Waksmundzka et al., 1984). This phenomenon was first described as periodic surface contraction waves appearing prior to the first cleavage divisions in amphibian and then documented in other species including sea urchin, starfish and mouse (Hara et al., 1980; Yoneda et al., 1982; Waksmundzka et al., 1984). Experiments in which one-cell mouse embryos were cut into nucleate and anucleate halves revealed that surface deformation that preceded first mitosis was autonomous of nuclear control and limited only to the first but not the following embryonic mitoses (Waksmundzka et al., 1984; Ciemerych, 1995; Ciemerych et al., 1998). MPF activity was also shown to be independent of cell nucleus but only in the first cell cycle (Ciemerych, 1995; Ciemerych et al., 1998). Further studies revealed more differences in the regulation of the two first embryonic mitoses (Ciemerych et al., 1999; Kubiak and Ciemerych, 2001; see also review by Kubiak et al., 2008, pp. 201-219 this issue). We showed that first mitosis was twice as long as the second and the third one. Observed prolongation did not depend on the activity of the spindle assembly checkpoint (Ciemerych et al., 1999; Sikora-Polaczek et al., 2006; see also review by Kubiak et al., 2008, pp. 201-219 this issue). We also proved that spindle assembly checkpoint is not involved in the CSF activity of metaphase II arrested oocytes. Thus we hypothesized that the prolongation of the first mitosis might rely on other factors, possibly the remnants of CSF activity (Sikora-Polaczek et al., 2006; see also review by Kubiak et al., 2008, pp. 201-219 this issue).

Apart from studying the cytoplasmic control of nuclear maturation during oogenesis and the first embryonic cell cycles, in other studies we tested the developmental performance of the dictyate nucleus of a primordial (resting) oocytes. We showed that when such nucleus is introduced into a fully-grown oocyte undergoing maturation, it completes normally the first meiotic division (Czolowska and Tarkowski, 1996). In the next study Waksmundzka et al. (1997) showed that such dictyate nucleus can be forced to proceed through two meiotic divisions and that thus formed haploid genome can substitute for the female pronucleus in preimplantation mouse development. This study was partly outpaced by a publication of Kono et al. (1996) who showed that diploid maternal genome of a non-growing oocyte that had undergone first meiotic division can support parthenogenetic development up to 13.5 day, i.e. for about 3 days longer than the genome of a fully grown oocyte.

\section{Cloning}

Our research of cloning proceeded along two pathways. All our studies on nucleo-cytoplasmic interactions confirmed earlier studies on non-mammalian species showing the crucial role of the cytoplasm in controlling the activity of the nucleus. Consequently, we concentrated on finding the optimal cytoplasmic conditions for remodeling of the embryonic and somatic nuclei placed in the egg 
cell. Nuclear transplantation experiments in amphibians conclusively showed that morphological remodelling precedes or coincides with functional remodelling, which leads to genetic reactivation of nuclei. In our experiments we introduced nuclei of blastomeres, foetal red blood cells, and somatic cells (thymocytes and follicle cells) to non-activated and activated oocytes and examined their behaviour at the light microscope level, and later, in collaboration with Dan and Maryna Szollosi, at the ultrastructural level. The most important lessons learned from these studies were that remodelling requires short (even very short) loss of the nuclear membrane and exposure to the cytoplasm of oocyte that had earlier undergone GVBD, and that in the activated oocyte the conditions that allow the denudation of the foreign nucleus disappear very quickly (Tarkowski and Balakier, 1980; Szollosi et al., 1986, 1988, 1998; Czolowska et al., 1984, 1992). Later studies were concentrated on the functional aspects of remodelling: transcription and DNA replication (Borsuk et al., 1996; Szollosi et al., 1998; Borsuk and Maleszewski, 2002).

The second route of our studies was aimed at testing the developmental potential of transplanted nuclei. Modlinski transplanted nuclei taken from mouse morulae into zygotes and found that resulting blastocysts were tetraploid and contained the genome derived from the transplanted nuclei (Modlinski, 1978). Undoubtedly, at that time this was a very important step forward. The serious weakness of this experiment, however, was that the zygote genome had not been removed. Although Modlinski developed earlier a microsurgical technique of enucleation of zygotes (Modlinski, 1975), he found that they could not survive double operation. In later studies, performed in collaboration with Smorag from Department of Animal Reproduction Biotechnology in Balice, (Modlinski and Smorag, 1991), they found that in the rabbit the nuclei taken from 8- and 16-cell embryos and transplanted to enucleated oocytes and zygotes are able to promote development to the blastocysts stage. Although better results were obtained using oocytes as recipient cells, successful development of enucleated zygotes carrying blastomere nucleus was striking.

In addition, we have also contributed to the success of cloning experiments in other laboratories by adapting the electrofusion method to mammalian embryos (Kubiak and Tarkowski, 1984). This method was used also by lan Wilmut and his collaborators to produce Dolly, the first mammal cloned from the nucleus of a differentiated somatic cell (Wilmut et al., 1997).

\section{Hybrid rodent embryos}

During the last 25 years we have repeatedly tried to produce hybrid rodent embryos, either by cross-fertilisation or by microsurgery and cell fusion. We have used four species: mouse, rat, Syrian hamster and bank vole. Cross-fertilisation is often impossible or hampered because of the non-permeability of the zona pellucida for foreign sperm or because of our inability to provide optimal conditions for sperm capacitation and fertilisation in vitro. Although removal of the zona pellucida usually permits crossfertilization, lack of this envelope precludes transfer of zygotes to the oviduct. If the technique of in vitroculturing one-cell embryos of a given species is not available, the experiment is limited to this particular stage. This dilemma is well illustrated by the experiment carried out by Witkowska (1982). She showed that fertilisation of zona-free rat eggs by mouse spermatozoa was possible, but a vice versa attempt was unsuccessful. The hybrid zygotes developed only to the 2-cell stage, either due to the nucleo-cytoplasmic incompatibility or inadequate culture conditions, or - and most likely - because of both reasons. To overcome these obstacles two experimental approaches were devised. In the first experiment Waksmundzka (1994) produced hybrid embryos by transferring a karyoplast containing rat spindle with metaphase II chromosomes or a karyoplast containing rat pronucleus under the zona pellucida of mouse oocytes, and fusing the two cells. If recipient mouse oocytes were in metaphase II they were either immediately activated in the presence of cytochalasin B to produce tetraploid hybrid parthenogenones, or were activated after removal of the mouse metaphase II in order to obtain diploid nucleo-cytoplasmic hybrids. Since the operated embryos had the zona pellucida, they could be transplanted to the mouse oviduct and, thus, developed in optimal conditions. The results were very disappointing: the majority of embryos stopped at 1- or 2-cell stage, and only a few cleaved up to 5-8 blastomeres (Waksmundzka, 1994). In the second experiment hybrids between the Syrian hamster and the mouse were produced by intracytoplasmic sperm injection (ICSI) of hamster spermatozoa into mouse eggs. In these hybrid zygotes both pronuclei replicated DNA and in G2 phase of the $1^{\text {st }}$ cell cycle both started transcription, and in the $2^{\text {nd }}$ cell cycle the hybrid nuclei replicated and transcribed. Nonetheless, the hybrid embryos invariably stopped to develop at the 2-cell stage (Krukowska, Borsuk and Tarkowski, unpublished results). Since our present culture conditions permit normal development of mouse zygotes, developmental failure of these hybrid embryos must have been due to an unidentified nucleo-cytoplasmic incompatibility. In view of the failure of the above-described experiments, Wroblewska, ZernickaGoetz and Tarkowski in a series of experiments (unpublished results) have tried to produce hybrid embryos by fusion of blastomeres taken from 2- and 8-cell mouse, rat and bank vole embryos. The rationale of this experiment -naive and erroneous as it turned out - was that functioning of the foreign genome would proceed more normally in the hybrid cytoplasm that in the cytoplasm of the foreign species. This presumption was not confirmed by experiments: development of all hybrid blastomeres stopped at the stage at which fusion was performed, or after one cell division. The only conclusion that can be drawn from these experiments is that the differences between the species used in these experiments involve very subtle molecular mechanisms essential for correct nucleo-cytoplasmic interactions, right from the beginning of the cleavage. Taking into account that in other animals lethality of hybrids does not occur before the initiation of transcription, and in mammals transcription starts from the very beginning of development, our results may not be as surprising as they look at the first sight.

\section{Regulation of transcription and DNA replication}

Mouse ovarian oocytes, as well as the one-cell embryos, are unique objects to study the mechanisms involved in the regulation of RNA and DNA synthesis. Mouse primary oocytes are arrested at the $G 2$ phase of the cell cycle. The last round of DNA replication occurs during the foetal life of the female, long before the oocytes enter the first meiotic division followed by the ovulation. Because during the entire period of oogenesis (including oocyte growth and maturation of fully-grown oocytes) replication would be an 


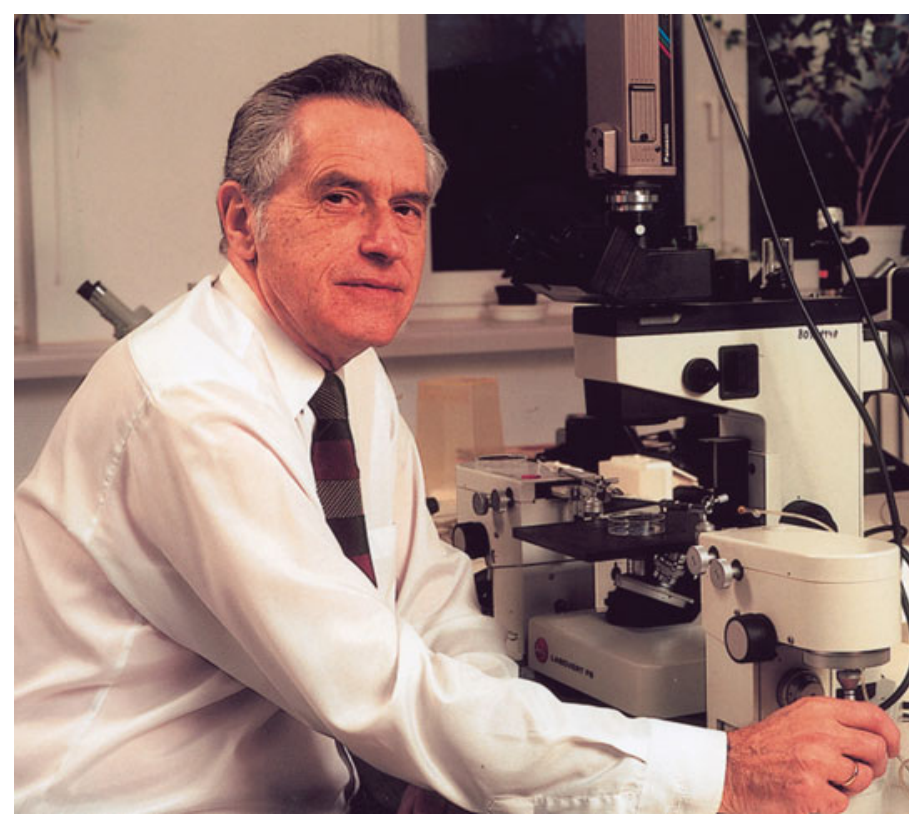

Fig. 6. Tarkowski in the laboratory at the Department of Embryology, a year before his retirement in 2003.

undesirable event, the oocytes developed powerful and reliable anti-replication mechanism. Such a mechanism, not allowing the new round of DNA replication before the cell passed through mitosis, is operating in somatic and embryonic G2 cells. However, we showed that the nuclei of growing mouse oocytes, obtained from sexually immature females, do not behave as nuclei in G2 (Czolowska and Borsuk, 2000). In hybrids formed between onecell parthenogenetic embryos and growing oocytes, DNA synthesis has been triggered in the nuclei of the latter and this reaction was not preceded by the nuclear envelope breakdown. This result suggested that the nuclei of growing oocytes are in a physiological state that is equivalent to replication-competent $\mathrm{G} 1$, and not G2 nuclei. Next, we have studied the presence and localization of proteins belonging to minichromosome maintenance complex (MCM) family, which are involved in the regulation of DNA synthesis. In somatic cells, these proteins are sequentially bound to chromatin during formation of pre-replicative complexes in G1 nuclei. After initiation of replication they gradually detach from chromatin and in G2 nuclei they are present only in the chromatinunbound form. This protects cells against undesirable DNA synthesis. To our surprise, we have discovered that the chromatinbound form of Mcm2 and Mcm7 are present in the nuclei of growing oocytes (Swiech et al., 2007). This observation confirmed the peculiarity of the nucleus of growing oocyte and suggests the existence of a unique mechanism protecting the genome of primary oocytes from the re-replication, which is different from the mechanism operating in somatic cells. We are still working on this subject, trying to find the key-regulator of repression of DNA synthesis in growing oocytes.

Another fascinating and still unsolved issue, is the regulation of the termination of transcription in fully-grown oocytes and its reinitiation in S/G2 one-cell embryos. RNA synthesis, activated in primordial oocytes simultaneously with the beginning of their growth, is maintained at a very high level until the oocyte achieves its final size. In fully-grown oocytes transcription is terminated many hours before initiation of maturation and condensation of bivalents. This unique phenomenon is accompanied by the condensation of chromatin and its accumulation around the nucleolus. The mechanism(s) that controls these two events remains unknown. It is still unclear whether the prolonged, transcriptionally repressive state of fully-grown oocytes is maintained actively by unknown cytoplasmic factor(s), or is the manifestation of inability of the nucleus to continue RNA synthesis. Using the cell fusion system, we have shown that the cytoplasm of fully-grown, transcriptionally inactive mouse oocytes, has the ability to silence RNA synthesis in the blastomere nuclei (Borsuk and Milik, 2005) and to delay significantly the onset of transcription in the female pronucleus (Zientarski and Borsuk, in preparation). In this latter case, we showed that accumulation of active form of RNA polymerase II in the pronucleus was also delayed.

RNA synthesis, which is silenced in fully-grown oocytes, is not initiated in one-cell embryos until S/G2 phase of the first cell cycle. The reasons for such a delay remain unclear. It has been postulated that the cytoplasm of one-cell mouse embryo at G1 is transcriptionally non-permissive and contains factors protecting the genome against premature onset of transcription. Our results showing that the cytoplasm of G1 parthenogenetic one-cell embryo has the ability to support the RNA synthesis in the foreign nucleus, introduced by the means of cell fusion, contradict this theory. Nuclei of transcribing somatic cells (murine erytroblastoma cells, MEL) continue transcription and those, which were transcriptionally inactive (thymocyte nuclei), restart it, and remain active until the end of the cell cycle (Borsuk et al., 1996; Borsuk and Maleszewski, 2002). These results suggest, that the cytoplasm of the early parthenogenetic one-cell embryo is transcriptionally permissive, but its genome is not ready for the initiation of RNA synthesis.

\section{Fertilisation}

Remodelling of the sperm nucleus and pronuclear growth. In 1980 we began studies on cytoplasmic control of the transformation of sperm nucleus into a male pronucleus in the mouse. At that time the method of bisection, which was originally developed for the cutting of one-cell embryos (Tarkowski and Rossant, 1976), was used to obtain nucleate and anucleate fragments of oocytes, at different stages of oogenesis. Next, these fragments were fertilised by sperm. We found that sperm nuclei underwent transformation into male pronuclei in both nucleate and anucleate halves of ovulated metaphase II (MII) oocyte (Tarkowski, 1980). Similar experiment was also performed with immature oocytes, which were bisected into nucleate and anucleate fragments before or after GVBD. Pairs of sister fragments were cultured until the nucleate fragments extruded the first polar body, and then the fragments were inseminated. In nucleate fragments the sperm nuclei underwent transformation into large pronuclei. In contrast, the behaviour of sperm nuclei in anucleate fragments depended on whether the fragments were isolated before or after GVBD. In the first case the sperm nuclei underwent only slight decondensation, whereas in fragments obtained after GVBD they transformed into large pronuclei (Balakier and Tarkowski, 1980). At that time our interpretation was that the content of the GV was essential for complete transformation of the sperm nucleus. Next, 
in experiments in which intact and bisected MII oocytes were fertilised in the presence of the antitubulin drug colcemide, we showed that the high level of the activity of MPF kinase was required for sperm decondensation. However, subsequent exit from the $M$ phase was necessary for successive formation of the male pronucleus (Borsuk and Manka, 1988).

In mouse, the transformation of the nucleus of a fertilising spermatozoon into a male pronucleus takes approximately 3 hours and occurs in dynamically changing cytoplasm of the activated oocyte. Fertilisation in vitro of zona-free oocytes, which were parthenogenetically activated is a convenient method to study the relationship between the phase of the mitotic cell cycle of the oocyte and the ability of its cytoplasm to transform the sperm nucleus. This approach makes possible to induce experimentally the asynchrony between oocyte activation and sperm penetration. Aldona Komar showed in her Ph.D thesis that artificially activated mouse oocytes do not develop the membrane block to polyspermy. These oocytes can be penetrated by spermatozoa even several hours after activation, and spermatozoa which entered these preactivated oocytes undergo at least partial transformation (Komar, 1979,1982). Later we demonstrated that the ability of the cytoplasm of artificially activated oocyte to decondense sperm chromatin disappears gradually during the first cell cycle of the parthenogenetic embryo (Borsuk and Tarkowski, 1989) and reappears during the first mitotic division (Maleszewski, 1992; 1995). However, the decondensastion of sperm chromatin does not necessarily indicate that this chromatin can undergo transformation into male pronucleus. In collaboration with Dan and Maryna Szollosi, we have demonstrated that the breakdown of the spermatozoon's nuclear envelope is a prerequisite for the transformation of the sperm nucleus into functional pronucleus (Borsuk and Tarkowski, 1989; Maleszewski 1990, 1992, Szollosi etal., 1990, Borsuk, 1991). However, Szollosi etal. (1994) showed that the decondensation of sperm chromatin is not fully preventable by the lack of sperm nuclear envelope breakdown. In the subsequent study we demonstrated that when the interval between oocyte activation and sperm incorporation does not exceed $1.5-2 \mathrm{hr}$, the spermatozoa transform into normal pronuclei, and the resulting embryos can develop to term. In contrast, when sperm nuclei are introduced into parthenogenotes $3 \mathrm{hr}$ or more after activation, their transformation into pronuclei is significantly impaired (Maleszewski et al., 1999).

In normal mammalian development, maternal and paternal haploid genomes form separate pronuclei. The question is whether this physical separation of the two genomes throughout the first cell cycle has developmental importance. Recently, we observed in some oocytes subjected to the procedure of intracytoplasmic sperm injection (ICSI) that maternal and paternal chromatin were surrounded by a common nuclear envelope and formed one diploid pronucleus. These 'monopronucleate' zygotes were able to develop in vitro into blastocysts, and after transfer to the pseudopregnant recipients developed until term (Krukowska and Tarkowski, 2005).

\section{Oolemma block to sperm penetration}

In normal mouse fertilisation cortical-granule-mediated reaction of zona pellucida seems to be a major mechanism preventing polyspermy (Wassarman, 1990). Evidence for the presence of a functional block to polyspermy at the level of the oocyte plasma membrane remains inconclusive. However, Maluchnik and Borsuk (1994) observed that when normally fertilised oocytes are freed from zonae pellucidae and reinseminated, additional spermatozoa are able to enter the oocytes if the second insemination occurs within $1 \mathrm{~h}$. This confirmed earlier observation of Wolf (1978) who showed that in mouse a block to polyspermy can develop in fertilised, zona-free oocytes. The mechanism of the oolemma block to sperm penetration remains obscure, but it seems to be independent of oocyte activation, since the oolemmae of parthenogenetically activated oocytes remain fusible with spermatozoa much longer than those of fertilised oocytes (Komar, 1979,1982; Borsuk and Tarkowski, 1989; Maleszewski, 1992). Several observations suggest that this block against sperm penetration is induced by sperm-oocyte fusion (Maleszewski and Bielak, 1993; Maleszewski et al., 1996; Pyrzynska et al., 1996), and can be induced in any cell that does not posses such a block (GV oocyte, MII oocyte, parthenogenetic embryo) by fusion with a cell that has already developed the block (zygote) (Krukowska et al., 1998). Oolemma block to sperm penetration probably prevents sperm fusion and has no effect on sperm binding (Maluchnik and Borsuk, 1994). The consequences of this block are similar to the fertilisation defects in mice oocytes, which are deficient in CD9 protein that is essential for the fusion of gametes (Kaji et al., 2000; Miyado et al., 2000). We investigated whether the loss of oolemma fusibility in mouse zygotes is linked to the changes of CD9 protein in the egg plasma membrane and demonstrated that CD9 protein is not directly involved in the formation of the oolemma block to sperm penetration (Komorowski et al., 2003). On the other hand, the ability of growing oocytes to fuse with spermatozoa seems to be related directly to the appearance of CD9 protein on oocyte surface (Komorowski et al., 2006).

\section{Activation of the oocyte}

Our interest in mechanisms of oocyte activation dates back to the experiments on artificial activation of mouse oocytes (Tarkowski et al., 1970). However, these studies were mostly aimed at evaluation of the developmental potential of parthenogenetic embryos, and not at the understanding of the mechanisms of activation itself (see above). Our first study on the control of oocyte activation during fertilisation, was performed by Kubiak (1989), who showed that after ovulation the MIl oocytes gradually develop the ability for activation. Soon after reaching MII stage (13 $\mathrm{h}$ after the administration of hCG) oocytes could be activated by the sperm, but not by the parthenogenetic agent (ethanol). Some of these young oocytes completed the $2^{\text {nd }}$ meiotic division and extruded the $2^{\text {nd }}$ polar body after stimulation with ethanol, but the chromosomes remained condensed and built a new spindle (metaphase III). These oocytes - when again activated - could enter interphase with a hypohaploid pronuclesus. However, the MIl oocytes, which were isolated $16-17.5 \mathrm{~h}$ after hCG, could be activated with equal efficiency by spermatozoa and by parthenogenetic factor.

Currently we know, that sperm specific isoform of phospholipase $C$, named phospholipase $\mathrm{C} \zeta(\mathrm{PLC} \zeta$ ) is a sperm-derived oocyte activating factor (Saunders et al., 2002). PLC $\zeta$ is introduced into the oocyte during fusion of the gametes, and induces activation of the oocyte. After the exit of the oocyte from the meiotic $M$ phase, the activity of PLC $\zeta$ is downregulated by its sequestration into the pronuclei (Larman et al., 2004; Yoda et al., 
2004). However, the first indication of the possibility that the sperm factor is maintained in the activated, fertilised oocyte came from the experiments performed in our department in collaboration with the group headed by dr. Bernard Maro from the Institute of Jacques Monod, CNRS, France (Zernicka-Goetz et al. (1995). These researchers have demonstrated, that when MII oocyte is fused with a zygote it undergoes activation. Such reaction is not observed after fusion of MII oocyte with parthenogenetic egg (see chapter Nucleo-cytoplasmic interactions in oocyte maturation and early development in this article for further details).

In our more recent experiments, we studied the mechanism responsible for the ability of the oocyte to be activated by a fertilising spermatozoon during meiotic maturation. Clarke and Masui (1986) showed that maturing murine oocytes, which had been penetrated by spermatozoa, were able to complete meiotic maturation, but did not undergo subsequent activation. Using the technique of cell fusion, we have demonstrated that sperm derived oocyte activating ability becomes inactivated in oocytes, which were fertilised prematurely, during meiotic maturation (Ajduk and Maleszewski, 2004). We also studied the calcium response of the oocytes, which were fertilised prematurely by ICSI soon after GVBD, and were refertilised after the completion of maturation. We demonstrated that in mouse oocytes the $\mathrm{Ca}^{2+}$ signalling pathway that is responsible for generation of $\left[\mathrm{Ca}^{2+}\right]_{i}$ oscillations during fertilisation and for activation of the oocyte, is not completely inactivated after premature penetration by spermatozoon. Thus, we have shown that in mouse oocyte, the molecular mechanism, which is involved in oscillatory $\mathrm{Ca}^{2+}$ response to fertilisation, can be switched on more than once (Jedrusik et al., 2007).

\section{Concluding remarks}

From 1954 when the Department of Embryology was established more than one hundred twenty students received here M.Sc. degree and more than twenty received Ph.D. degree. The first members of the academic staff have already retired, but fortunately they still continue to be active in science. Some research topics studied in those remote times are being continued (regulative capabilities of early embryos, chimaerism) and some simple experimental techniques are being continuously used (embryo culture in vitro and transfer, bisection of oocytes and early embryonic cells, cell fusion). At the same time, a number of new research topics have been introduced (mechanism of egg activation, regulation of transcription and replication in oogenesis and early development) and new cytological, immunohistochemical and molecular techniques have widened our methodological repertoire. We have experienced better and worse times, and have had ups and downs in our research activity but we have never lost our fascination with mammalian oocytes and embryos. Hopefully, the ontogenesis of our Department will continue to proceed smoothly without 'harmful mutations and developmental defects'.

\section{Acknowledgements}

We wish to thank all our colleagues, current and former members of the departmental staff, as well as all students preparing their M.Sc. and Ph.D. thesis in our laboratory for their enthusiastic involvement in research described in this article. We thank those of our colleagues who actually work in the Department and those who work now elsewhere, but with whom we maintain close contacts, for critical reading of this article and for many helpful comments, Drs. Renata Czolowska and Jacek Kubiak deserve special thanks. We apologize for not mentioning all people working in our laboratory and not quoting all papers published during over 50-year history of the Department of Embryology.

\section{References}

AJDUK, A. and MALESZEWSKI, M. (2004). Sperm-derived activity ability does not persist in mouse oocytes inseminated during in vitro maturation. Mol. Reprod. Dev. 68: 240-249.

BALAKIER, H. (1978). Induction of maturation in small oocytes from sexually immature mice by fusions with meiotic or mitotic cells. Exp. Cel/ Res. 112: 137141.

BALAKIER, H. (1979). Interspecific heterokaryons between oocytes and blastomeres of the mouse and the bank vole. J. Exp. Zool. 209: 323-329.

BALAKIER, H. AND CZOLOWSKA, R. (1977). Cytoplasmic control of nuclear maturation in mouse oocytes. Exp. Cell Res. 110: 466-470.

BALAKIER, H., TARKOWSKI, A.K. (1976). Diploid parthenogenetic mouse embryos produced by heat-shock and cytochalasin B. J. Embryol. Exp.Morph. 35: 25-39.

BALAKIER, H. and TARKOWSKI, A.K. (1980). The role of germinal vesicle karyoplasm in the development of male pronucleus in the mouse. Exp. Cell Res.128: 79-85.

BORSUK, E. (1982). Preimplantation development of gynogenetic diploid mouse embryos. J. Embryol. Exp. Morph. 69: 215-222.

BORSUK, E. (1991). Anucleate fragments of parthenogenetic eggs and of maturing oocytes contain complementary factors required for development of a male pronucleus. Mol. Reprod. Dev. 29: 150-156.

BORSUK, E. and MALESZEWSKI, M. (2002). DNA replication and RNA synthesis in thymocyte nuclei microinjected into the cytoplasm of artificially activated mouse eggs. Zygote 10, 229-238.

BORSUK, E. and MANKA, R. (1988). Behavior of sperm nuclei in intact and bisected metaphase II mouse oocytes in the presence of colcemid. Gamete Res. 20: 365-367.

BORSUK, E. AND MILIK, E. (2005). Fully grown mouse oocyte contains transcription inhibiting activity which acts through histone deacetylation. Mol. Reprod. Dev. 71: 509-515.

BORSUK, E., SZOLLOSI, M.S., BESOMBES, D. AND DEBEY, P. (1996). Fusion with activated mouse oocytes modulates the transcriptional activity of introduced somatic cell nuclei. Exp. Cell Res. 225: 93-101.

BORSUK, E. and TARKOWSKI, A.K. (1989). Transformation of the sperm nuclei into male pronuclei in nucleate and anucleate fragments of parthenogenetic mouse eggs. Gamete Res. 24: 471-481.

CHROSCICKA, A., KOMOROWSKI, S. and MALESZEWSKI, M. (2004). Both blastomeres of the mouse 2-cell embryo contribute to the embryonic portion of the blastocyst. Mol. Reprod. Dev. 68: 308-312.

CIEMERYCH, M.A. (1995). Chromatin condensation activity and cortical activity during the first three cell cycles of a mouse embryo. Mol Reprod Dev. 41: 416424.

CIEMERYCH, M.A. and CZOLOWSKA, R. (1993). Differential chromatin condensation of female and male pronuclei in mouse zygotes. Mol Reprod Dev. 34: 7380.

CIEMERYCH, M.A. and KUBIAK, J.Z. (1998). Cytostatic activity develops during meiosis in oocytes of Lt/Sv mice. Dev. Biol. 200: 198-211.

CIEMERYCH, M.A. and KUBIAK, J.Z. (1999). Transient reactivation of CSF in parthenogenetic one-cell mouse embryos. Biol. Cell 91: 641-647.

CIEMERYCH, M.A., MARO, B. and KUBIAK, J.Z. (1999). Control of duration of the first two mitoses in a mouse embryo. Zygote 7: 293-300.

CIEMERYCH, M.A., TARKOWSKI, A.K. and KUBIAK, J.Z. (1998). Autonomous activation of histone $\mathrm{H} 1$ kinase, cortical activity and microtubule organization in one- and two-cell mouse embryos. Biol. Cell 90: 557-564.

CLARKE, H. J. and MASUI, Y. (1986). Transformation of sperm nuclei to metaphase chromosomes in the cytoplasm of maturing oocytes of the mouse. J. Cell Biol. 102: 1039-1046. 
CZOLOWSKA, R. and BORSUK, E. (2000). Induction of DNA replication in the germinal vesicle of the growing mouse oocyte. Dev. Biol. 223: 205-215.

CZOLOWSKA, R., MODLINSKI, J.A. and TARKOWSKI, A.K. (1984). Behaviour of thymocyte nuclei in non-activated and activated mouse oocytes. J. Cel/ Sci. 69: 19-34.

CZOLOWSKA, R., SZOLLOSI, D. AND SZOLLOSI, M. S. (1992). Changes in embryonic 8-cell nuclei transferred by means of cell fusion to mouse eggs. Int. J. Dev. Biol. 36: 543-553.

CZOLOWSKA, R. AND TARKOWSKI, A.K. (1996). First meiosis of early dictyate nuclei from primordial oocytes in mature and activated mouse oocytes. Zygote 4: 73-80.

CZOLOWSKA, R., WAKSMUNDZKA, M., KUBIAK, J.Z. and TARKOWSKI, A.K. (1986). Chromosome condensation activity in ovulated metaphase II oocytes assayed by fusion with interphase blastomeres. J. Cel/ Sci. 84: 129-138.

DEHNEL, G. (1929a). Studies on development and origin of composite malformations in the freshwater turtle (Emys orbicularis L.). Arch. Nauk Biol. Tow. Nauk. Warsz. 2: 1-68. (in Polish)

DEHNEL, G. (1929b). Blastotomie experimentale des germes d'Oiseaux. C.R.Soc.Biol. Paris 100: 258-259.

DEHNEL, G. (1933). Regulative processes in the artificially transected avian embryos. Kosmos A, 58: 53-64. (In Polish)

GRAHAM, C.F. (1970). Parthenogenetic mouse blastocysts. Nature226: 165-167.

HARA, K., TYDEMAN, P. and KIRSCHNER, M. (1980). A cytoplasmic clock with the same period as the division cycle in xenopus eggs. Proc Nat/ Acad Sci USA77: 462-466.

JEDRUSIK, A., AJDUK, A., POMORSKI, P. and MALESZEWSKI, M. (2007). Mouse oocytes fertilised by ICSI during in vitro maturation retain the ability to be activated after reinsemination in metaphase II and can generate $\mathrm{Ca}^{2+}$ oscillations. BMC Dev. Biol. 7, 72.

KAJI, K., ODA, S., SHIKANO, T., OHNUKI, T., UEMATSU, Y., SAKAGAMI, J., TADA, N., MIYAZAKI, S. and KUDO, A. (2000). The gamete fusion process is defective in eggs of CD9 deficient mice. Nat. Genet. 24: 279-282.

KAUFMAN, M.H., BARTON, S.C. and SURANI, M.A.H. (1977). Normal postimplantation development of mouse parthenogenetic embryos to the forelimb bud stage. Nature 265: 53-55.

KLOC, M. (2008). Basic Science B.D. (before Drosophila): Cytology at Warsaw University (Poland). Int. J. Dev. Biol. 52: 115-119.

KOMAR, A. (1973). Parthenogenetic development of mouse eggs activated by heat-shock. J. Reprod. Fert. 35: 433-443.

KOMAR, A. (1979). Fertilisation in vitro of parthenogenetically activated mouse eggs. Ph.D. Thesis, Department of Embryology, Warsaw University (In Polish).

KOMAR, A. (1982). Fertilization of parthenogenetically activated mouse eggs. I. Behaviour of sperm nuclei in the cytoplasm of parthenogenetically activated eggs. Exp. Cell Res. 139: 361-367.

KOMOROWSKI, S., SZCZEPANSKA, K. and MALESZEWSKI, M. (2003). Distinct mechanisms underline sperm-induced and protease induced oolemma block to sperm penetration. Int. J. Dev. Biol. 47: 65-69.

KOMOROWSKI, S., BARANOWSKA, B. and MALESZEWSKI, M. (2006). CD9 protein appears on growing mouse oocytes at the time when they develop the ability to fuse with spermatozoa. Zygote 14: 119-123.

KONO, T., CARROLL, J., SWANN, K. and WHITTINGHAM, D.G. (1995). Nuclei from fertilized mouse embryos have calcium-releasing activity. Development 121: 1123-1128.

KONO, T., OBATA, Y., YOSHIMZU, T., NAKAHARA, T. and CARROLL, J. (1996). Epigenetic modifications during oocyte growth correlate with extended parthenogenetic development in the mouse. Nature Genetics 13: 91-94.

KRUKOWSKA, A. AND TARKOWSKI, A.K. (2005). Mouse zygotes with one diploid pronucleus formed as a result of ICSI can develop normally beyond birth. Mol. Reprod. Dev. 72: 346-353.

KRUKOWSKA, A., WIELKOPOLSKA, E., CZOLOWSKA, R., MALESZEWSKI, M. and TARKOWSKI, A.K. (1998). Mouse oocytes and parthenogenetic eggs lose the ability to be penetrated by spermatozoa after fusion with zygotes. Zygote6: 321-328.

KUBIAK, J.Z. (1989). Mouse oocytes gradually develop the capacity for activation during the metaphase II arrest. Dev. Biol. 136: 537-545.
KUBIAK, J.Z. and CIEMERYCH, M.A. (2001). Cell cycle regulation in early mouse embryos. Novartis Found Symp 237: 79-89; discussion: 89-99.

KUBIAK, J. Z. AND TARKOWSKI, A.K. (1985). Electrofusion of mouse blastomeres. Exp. Cell Res. 157: 561566.

KUBIAK, J.Z., WEBER, M., DE PENNART, H., WINSTON, N.J. and MARO, B. (1993). The metaphase II arrest in mouse oocytes is controlled through microtubule-dependent destruction of cyclin $\mathrm{B}$ in the presence of csf. EMBOJ. 12: 3773-3778.

KUBIAK, J.J., CIEMERYCH, M.A., HUPALOWSKA, A., SIKORA-POLACZEK, M. and POLANSKI, Z. (2008). On the transition from the meiotic to mitotic cell cycle during early mouse development. Int. J. Dev. Biol. 52: 201-217.

KUWANA, T. and ROGULSKA, T. (1999). Migratory mechanisms of chick primordial germ cells toward gonadal anlage. Cell Mol. Biol. 45: 725-736.

LARMAN, M.G., SAUNDERS, C.M., CARROL, J., LAI, A. and SWAN, K. (2004). Cell cycle-dependent $\mathrm{Ca}^{2+}$ oscillations in mouse embryos are regulated by nuclear targeting of PLC2. J. Cel/ Sci. 117: 2513-2521.

MALESZEWSKI, M. (1990). Decondensation of mouse sperm chromatin in cell-free extracts: a micromethod. Mol. Reprod. Dev. 27: 244-248.

MALESZEWSKI, M. (1992). Behavior of sperm nuclei incorporated into parthenogenetic mouse eggs prior to the first cleavage division. Mol. Reprod. Dev. 33: 215-221.

MALESZEWSKI, M. (1995). Sperm nuclei entering parthenogenetically activated mouse oocytes before the first mitosis transform into pronuclei. An ultrastructural study. Anat. Rec. 243: 516-518.

MALESZEWSKI, M. and BIELAK, A. (1993). Sperm penetration in parthenogenetic mouse embryos triggers a plasma membrane block to polyspermy. Zygote 1: 237-242.

MALESZEWSKI, M., BORSUK, E., KOZIAK, K., MALUCHNIK, D. and TARKOWSKI, A.K. (1999). Delayed sperm incorporation into parthenogenetic mouse eggs: sperm nucleus transformation and development of resulting embryos. Mol. Reprod. Dev. 54: 303-310.

MALESZEWSKI, M., KIMURA, Y. and YANAGIMACHI, R. (1996). Sperm membrane incorporation into oolemma contributes to the oolemma block to sperm penetration: evidence based on intracytoplasmic sperm injection experiments in the mouse. Mol. Reprod. Dev. 44: 256-259.

MALUCHNIK, D. and BORSUK, E. (1994). Sperm entry into fertilised mouse eggs. Zygote 2: 129-131.

MASUI, Y. and MARKERT, C.L. (1971). Cytoplasmic control of nuclear behavior during meiotic maturation of frog oocytes. J. Exp. Zool. 177: 129-145.

McGRATH, J. and SOLTER, D. (1984). Completion of mouse embryogenesis requires both the maternal and paternal genomes. Ce//37: 179-183.

MIYADO, K., YAMADA, G., YAMADA, S., HASUWA, H., NAKAMURA, Y., RYU, F., SUZUKI, K., KOSAI, K., INOUE, K., OGURA, A., OKABE, M. and MEKADA, E. (2000). Requirement of CD9 on the egg plasma membrane for fertilization. Science 287: 321-324.

MODLINSKI, J. A. (1975). Haploid mouse embryos obtained by microsurgical removal of one pronucleus. J. Embryol. Exp. Morph. 33: 897-905.

MODLINSKI, J.A. (1978). Transfer of embryonic nuclei to fertilised mouse eggs and development of tetraploid blastocysts. Nature 273: 466-467.

MODLINSKI, J.A. AND SMORAG Z. (1991). Preimplantation development of rabbit embryos after transfer of embryonic nuclei into different cytoplasmic environment. Mol. Reprod. Dev. 28: 361-372.

MYSTKOWSKA, E.T. (1975a). Preimplantation development in vivo and in vitro in bank voles, Clethrionomys glareolus, treated with PMSG and HCG. J. Reprod. Fert. 42: 287-292.

MYSTKOWSKA, E.T. (1975b). Development of mouse-bank vole interspecific chimaeric embryos. J. Embryol. Exp. Morph. 33: 731-744.

MYSTKOWSKA, E.T., OZDZENSKI, W. AND NIEMIERKO, A. (1979). Factors regulating the degree and extent of experimental chimaerism in the mouse. $J$. Embryol. Exp. Morph. 51: 217-225.

MYSTKOWSKA, E.T. AND TARKOWSKI, A.K. (1968). Observations on CBA/pCBA-T6T6 mouse chimeras. J. Embryol. Exp. Morph. 20: 33-52.

MYSTKOWSKA, E.T. and TARKOWSKI, A.K. (1970). Behaviour of germ cells and sexual differentiation in late embryonic and early postnatal mouse chimaeras. J. Embryol. Exp. Morph. 23: 395-405. 
NAGY, A., GOCZA, E., DIAZ, E.M., PRIDEAUX, V.P., IVANYI, E., MARRKULA,M. and ROSSANT, J. (1990). Embryonic stem cells alone are able to support fetal development in the mouse. Development 110: 815-821.

NIEMIERKO, A. (1975). Induction of triploidy in the mouse by cytochalasin B. J. Embryol. exp. Morph. 34: 279-289.

OPAS, J. (1977). Effects of extremely low osmolarity on fertilized mouse eggs. J. Embryol. Exp. Morph. 37: 65-77.

OZDZENSKI, W. (1967). Observations on the origin of primordial germ cells in the mouse. Zool. Pol. 17: 367-379.

OZDZENSKI, W. (1969). Fate of primordial germ cells in the transplanted hind gut of mouse embryos. J. Embryol. Exp. Morph. 22: 505-510.

OZDZENSKI, W. (1972). Differentiation of the genital ridges of mouse embryos in the kidney of adult mice. Arch. Anat. Microsc. Morph. Exp. 61, 267-278.

OZDZENSKI, W. and MYSTKOWSKA, E.T. (1976a). Stages of pregnancy of the bank vole. Acta Theriol. 21: 279-286.

OZDZENSKI, W. and MYSTKOWSKA, E.T. (1976b). Implantation and early postimplantation development of the bank vole Clethrionomys glareolus, Schreber. J. Embryol. Exp. Morph. 35: 535-543.

OZDZENSKI, W. AND PRESZ, M. (1984). Precocious initiation of meiosis by male germ cells of the mouse. Arch. Anat. Microsc. Morph. Exp. 73: 1-7.

OZDZENSKI, W., SZCZESNY, E. AND TARKOWSKI, A.K. (1997). Postimplantation development of mouse blastocysts with two separate inner cell masses. Anat. Embryol. 195: 467-471.

PIOTROWSKA-NITSCHE, K., PEREA-GOMEZ, A., HARAGUCHI, S. and ZERNICKA-GOETZ, M. (2005). Four-cell stage mouse blastomeres have different developmental properties. Development 132: 479-490.

PYRZYNSKA, B., MALESZEWSKI, M. and MALUCHNIK, D. (1996). Mouse oocytes penetrated by sperm at GV or GVBD stage lose the ability to fuse with additional spermatozoa. Zygote 4: 123-128.

REIK, W., SANTOS, F., MITSUYA, K., MORGAN, H. and DEAN, W. (2003). Epigenetic asymmetry in the mammalian zygote and early embryo: relationship to lineage commitment? Phil. Trans. R. Soc. Lond. B358: 1403-1409.

ROGULSKA, T. (1968a). The effect of transection of the duck blastoderm on the orientation of the embryo. J. Embryol. Exp. Morph. 20: 237-245.

ROGULSKA, T. (1968b). Primordial germ cells in normal and transected duck blastoderms. J. Embryol. Exp. Morph. 20: 247-260.

ROGULSKA. T., KLOTZ, A.G. and LASZCZYCH-LUPINSKA, J. (1992). Influence of chick or quail embryonic testes on the reproductive system of the quail embryo. Biol. Struct. Morph. 4: 23-27.

ROGULSKA, T., OZDZENSKI, W. and KOMAR, A. (1971). Behaviour of mouse primordial germ cells in the chick embryo. J. Embryol. Exp. Morph. 25, 155-164.

ROGULSKA, T. and ZAJAC, H. (1986-1987). Meiotic prophase in the left embryonic testis of the Japanese quail (Coturnix coturnix japonica L.). Arch. Anat. Micr. Morph. Exp. 75: 127-134.

ROMANOFF, A.L. (1960). The Avian Embryo. The Macmillan Company, New York. pp 1305.

ROSSANT, J. (1976). Postimplantation development of blastomeres isolated from 4- and 8-cell mouse eggs. J. Embryol. Exp. Morph. 36: 283-290.

SAUNDERS, C. M., LARMAN, M. G., PARRINGTON, J., COX, L. J., ROYSE, J., BLAYNEY, L. M., SWANN, K. and LAI, F. A. (2002). PLC zeta: a sperm-specific trigger of $\mathrm{Ca}(2+)$ oscillations in eggs and embryo development. Development 129: 3533-3544.

SIKORA-POLACZEK, M., HUPALOWSKA, A., POLANSKI, Z., KUBIAK, J.Z. and CIEMERYCH, M.A. (2006). The first mitosis of the mouse embryo is prolonged by transitional metaphase arrest. Biol. Reprod. 74: 734-743.

SNOW, M.H.L. (1973). Tetraploid mouse embryos produced by cytochalasin B during cleavage. Nature 244: 513-515.

SURANI, M.A.H., BARTON, S.C. and NORRIS, M.L. (1984). Development of reconstituted mouse eggs suggests imprinting of the genome during gametogenesis. Nature 308: 548-550.

SUWINSKA, A., OZDZENSKI, W., WAKSMUNDZKA, M. and TARKOWSKI, A.K. (2005). Experimentally produced diploid<->triploid mouse chimaeras develop up to adulthood. Mol. Reprod. Dev. 72: 362-376

SWIECH, L., KISIEL, K., CZOLOWSKA, R., ZIENTARSKI, M. AND BORSUK, E.
(2007). Accumulation and dynamics of proteins of MCM family during mouse oogenesis and first embryonic cell cycle. Int. J. Dev. Biol. 51, 283-295.

SZOLLOSI, M.S., BORSUK, E. and SZOLLOSI, D. (1994). Relationship between sperm nucleus remodelling and cell cycle progression of fragments of mouse parthenogenotes. Mol. Reprod. Dev. 37: 146-156.

SZOLLOSI, D., CZOLOWSKA, R., BORSUK, E., SZOLLOSI, M.S. and DEBEY, P. (1998). Nuclear envelope removal/maintenance determines the structural and functional remodelling of embryonic red blood cell nuclei in activated mouse oocytes. Zygote 6: 65-73.

SZOLLOSI, D., CZOLOWSKA, R., SOLTYNSKA, M. S. AND TARKOWSKI, A.K. (1986). Ultrastructure of cell fusion and premature chromosome condensation (PCC) of thymocyte nuclei in metaphase II mouse oocytes. Biol. Ce//56, 239 250.

SZOLLOSI, D., CZOLOWSKA, R., SZOLLOSI, M. S. AND TARKOWSKI, A.K. (1988). Remodelling of mouse thymocyte nuclei depends on the time of their transfer into activated, homologous oocytes. J. Cel/ Sci. 91: 603613.

SZOLLOSI, D., SZOLLOSI, M.S., CZOLOWSKA, R. and TARKOWSKI, A.K(1990). Sperm penetration into immature mouse oocytes and nuclear changes during maturation: an EM study. Biol. Cell 69: 53-64.

TARKOWSKI. A.K. (1959a). Experiments on the development of isolated blastomeres of mouse eggs. Nature 184: 1286-1287.

TARKOWSKI, A.K. (1959b). Experimental studies on regulation in the development of isolated blastomeres of mouse eggs. Acta Theriol. 3: 191-267.

TARKOWSKI, A.K. (1961). Mouse chimaeras developed from fused eggs. Nature 190: 857-860.

TARKOWSKI, A.K. (1977). In vitro development of haploid mouse embryos produced by bisection of one-cell fertilized eggs. J. Embryol. Exp. Morph. 38: 187202.

TARKOWSKI, A.K. (1980). Fertilization of nucleate and anucleate egg fragments in the mouse. Exp. Cell Res. 128:73-77.

TARKOWSKI, A.K., BALAKIER, H. (1980). Nucleo cytoplasmic interactions in cell hybrids between mouse oocytes, blastomeres and somatic cells. J. Embryol. Exp. Morph. 55: 319330.

TARKOWSKI, A.K., JAGIELLO, K., CZOLOWSKA, R. AND OZDZENSKI, W. (2005b). Mouse chimaeras developed from electrofused blastocysts: new evidence for developmental plasticity of the inner cell mass. Int. J. Dev. Biol. 49: 909-914.

TARKOWSKI, A.K., OZDZENSKI, W. and CZOLOWSKA, R. (2001a). Mouse singleton and twins developed from isolated diploid blastomeres supported with tetraploid blastomeres. Int. J. Dev. Biol. 45: 591-596.

TARKOWSKI, A.K, OZDZENSKI, W. and CZOLOWSKA, R. (2001b). How many blastomeres of the 4-cell embryo contribute cells to the mouse body? Int. J. Dev. Biol. 45: 811-816

TARKOWSKI, A.K., OZDZENSKI, W. and CZOLOWSKA, R. (2005a). Identical triplets and twins developed from isolated blastomeres of 8- and 16-cell mouse embryos supported with tetraploid blastomeres. Int. J. Dev. Biol. 49: 825-832.

TARKOWSKI, A.K. and ROSSANT, J. (1976). Haploid mouse blastocysts developed from bisected zygotes. Nature 259: 663-665.

TARKOWSKI, A.K., WITKOWSKA, A. and NOWICKA, J. (1970). Experimental parthenogesis in the mouse. Nature 226: 162-165.

TARKOWSKI, A.K., WITKOWSKA, A. and OPAS, J. (1977). Development of cytochalasin B-induced tetraploid and diploid/tetraploid mosaic mouse embryos. J. Embryol. Exp. Morph. 41: 47-64.

TARKOWSKI, A.K. and WOJEWODZKA, M. (1982). A method for obtaining chimaeric mouse blastocysts with two separate inner cell masses: a preliminary report. J. Embryol. Exp. Morph. 71: 215-221.

TARKOWSKI, A.K. and WROBLEWSKA, J. (1967). Development of blastomeres of mouse eggs isolated at the 4- and 8-cell stage. J. Embryol. Exp. Morph.18: 155180.

TUR, J. (1904). Sur les malformations embryonnaires obtenues par l'action du radium sur les oeufs de la poule. C. R. Soc. Biol. 57: 236-238.

UPADHYAY, S. and ZAMBONI, L. (1982). Ectopic germ cells: natural model for the study of germ cell sexual differentiation. Proc. Natl. Acad. Sci. USA 79: 65846588.

WAKSMUNDZKA, M. (1994). Development of rat x mouse hybrid embryos pro- 
duced by microsurgery. J. EXp. Zool. 269: 551-559.

WAKSMUNDZKA, M., CZOLOWSKA, R. AND TARKOWSKI, A.K. (1997). Haploid maternal genome derived from early diplotene oocytes can substitute for the female pronucleus in preimplantation mouse development. Mol. Reprod. Dev. 48: 488-495.

WAKSMUNDZKA, M., KRYSIAK, E., KARASIEWICZ, J., CZOLOWSKA, R. and TARKOWSKI, A.K. (1984). Autonomous cortical activity in mouse eggs controlled by a cytoplasmic clock. J. Embryol. Exp. Morphol. 79: 77-96.

WAKSMUNDZKA, M., WISNIEWSKA, A. and MALESZEWSKI, M. (2006). Allocation of cells in mouse blastocyst is not determined by the order of cleavage of the first two blastomeres. Biol. Reprod. 75: 582-587.

WASSARMAN, P.M. (1990). Profile of the mammalian sperm receptor. Development 108: 1-17.

WILMUT, I., SCHNIEKE, A.E., McWHIR, J., KIND, A.J. and CAMPBELL, K.H. (1997). Viable offspring derived from fetal and adult mammalian cells. Nature 385: 810-813.

WITKOWSKA, A. (1973a). Parthenogenetic development of mouse embryos in vivo. I. Preimplantation development. J. Embryol. Exp. Morph. 30: 519-545.

WITKOWSKA, A. (1973b). Parthenogenetic development of mouse embryos in vivo. II. Postimplantation development. J. Embryol. Exp. Morph. 30: 547-560.

WITKOWSKA, A. (1982). Fertilisation of zona-free rat eggs with mouse spermatozoa: the fate of sperm nuclei up to the first cleavage division. Folia Biol. (Krakow)
30: 105-112.

WOLF, D.P. (1978). The block to sperm penetration in zona-free mouse eggs. Dev. Biol. $64: 1-10$.

WROBLEWSKA, J. (1971). Developmental anomaly in the mouse associated with triploidy. Cytogenetics 10, 199-207

YODA, A., ODA, S., SHIKANO, T., KOUCHI, Z., AWAJI, T., SHIRAKAWA, H., KINOSHITA, K. and MIYAZAKI, S. (2004). $\mathrm{Ca}^{2+}$ oscillation-inducing phospholipase $C$ zeta expressed in mouse eggs is accumulated to the pronucleus during egg activation. Dev. Biol. 268: 245-257.

YONEDA, M., KOBAYAKAWA, Y., KUBOTA, H.Y. and SAKAI, M. (1982). Surface contraction waves in amphibian eggs. J. Cell Sci. 54: 35-46.

ZERNICKA-GOETZ, M. (2002). Patterning of the embryo: the first spatial decisions in the life of a mouse. Development 129: 815-829.

ZERNICKA-GOETZ, M. (2005). Cleavage pattern and emerging asymmetry of the mouse embryo. Nature Rev. Mol. Cell Biol. 6: 919-928.

ZERNICKA-GOETZ, M. (2006). The first cell-fate decisions in the mouse embryo: destiny is a matter of both chance and choice. Cur. Op. Genet. Dev. 16:406-412.

ZERNICKA-GOETZ, M., CIEMERYCH, M.A., KUBIAK, J.Z., TARKOWSKI, A.K. and MARO, B. (1995). Cytostatic factor inactivation is induced by a calciumdependent mechanism present until the second cell cycle in fertilized but not in parthenogenetically activated mouse eggs. J. Cell Sci. 108: 469-474.

\section{Related, previously published Int. J. Dev. Biol. articles}

See our recent Special Issue Developmental Biology in Poland edited by Kloc, Maleszewski and Tarkowski at:

http://www.ijdb.ehu.es/web/contents.php?vol=52\&issue=2-3

See our Special Issue Mammalian Reproduction \& Development in honor of Anne McLaren and edited by Brigid Hogan at:

http://www.ijdb.ehu.es/web/contents.php?vol=45\&issue=3

\author{
A history of normal plates, tables and stages in vertebrate embryology \\ Nick Hopwood \\ Int. J. Dev. Biol. (2007) 51: 1-26
}

Polyembryony in parasitic wasps: evolution of a novel mode of development. Miodrag Grbic

Int. J. Dev. Biol. (2003) 47: 633-642

My perpetual cycle: from student to researcher to teacher to student

Robert Vignali

Int. J. Dev. Biol. (2003) 47: 203-211

The early history of the polarizing region: from classical embryology to molecular biology.

Cheryll Tickle

Int. J. Dev. Biol. (2002) 46: 847-852

Developmental basis of limb evolution.

$J$ Richard Hinchliffe

Int. J. Dev. Biol. (2002) 46: 835-845

From development to evolution: the re-establishment of the "Alexander Kowalevsky Medal".

Alexander T Mikhailov and Scott F Gilbert

Int. J. Dev. Biol. (2002) 46: 693-698

The beginnings of developmental biology in Swiss universities. Rudolf Weber

Int. J. Dev. Biol. (2002) 46: 15-22

The role of Otx2 in organizing the anterior patterning in mouse. A Simeone and D Acampora

Int. J. Dev. Biol. (2001) 45: 337-345

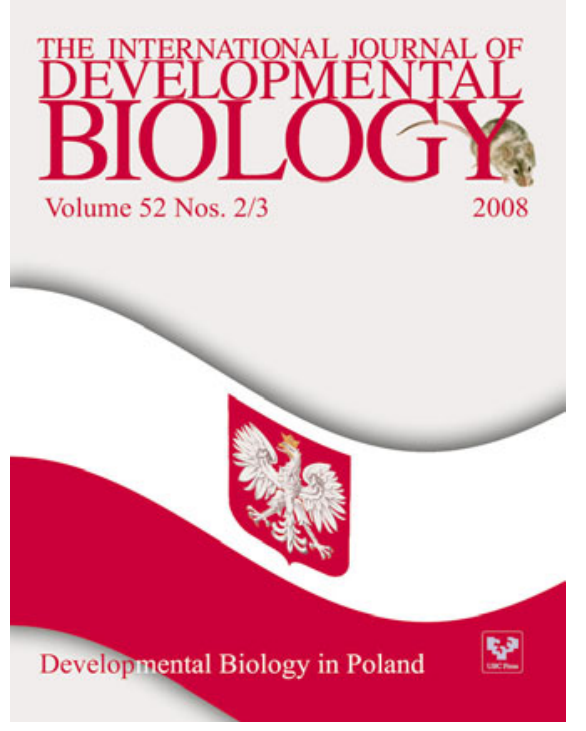

2006 ISI ${ }^{* *}$ Impact Factor $=3.577^{\star *}$

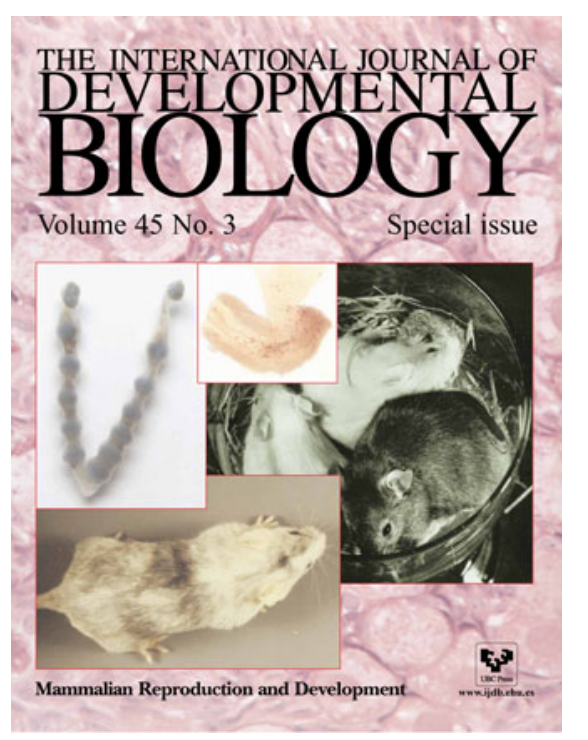

